\title{
The Monastery of Deçan and the Attempts to Appropriate It
}

\author{
Arben Arifi \\ Dr., College "UBT", \\ Pristina, Kosovo \\ Luan Tetaj \\ Prof. Ass. Dr., Institute of History, \\ Pristina, Kosovo
}

\begin{abstract}
The Monastery of Deçan is a monument of cultural heritage in Deçan-Kosova. The monastery was built in the 14th century, and is listed at the UNESCO monuments list. The monastery of Deçan is considered one of the most important cultural and monumental building pertaining to the medieval period in Kosova and in the region in general. The paper deals especially with the historical aspect of its existence as well as its architectonic properties. The architecture of monastery of Deçan is characterized by Byzantine elements, but one can also observe Roman Italian elements in its architecture. The attempts to appropriate and assimilate the historical and cultural background that is characteristic to the monastery, and classify it as a Serbian monastery are numerous and often times lack sufficient scientific basis. The monastery of Deçan, with its Roman-Gothic architecture and its unique history enriches the cultural mosaic of cultural heritage in Kosova, and as such it is part of the culture of all Kosovars.
\end{abstract}

Keywords: Deçan, Monastery, Architecture, Vita Kuçi

\section{Introduction}

The monastery of Deçan is situated in the municipality of Deçan, in the western part of Kosova, and it borders with the municipality of Peja, Gjakova, and the Republic of Albania. Its position at the foot of the mountains creates an imposing natural attraction, thus depicting a wonderful scenic imagery. From a religious perspective, the monastery of Deçan is identified through the Orthodox Church. The monastery of Deçan is considered one of the most important monumental and cultural buildings of the medieval period in Kosova and abroad.

The author Laurent Mitchell in his Guidebook describes the monastery in this manner: The monastery's assembly of buildings is situated behind a large wall, which one crosses through a large fortified gate. Only some of the monastery's original buildings remain to this day, including the central part of the monastery which is the Church of Christ-Pantocrator, an opus of the Franciscan monk from Kotor, named Vid. The church, which represents an interesting combination of the Western tradition with the Byzantine 


\section{Journal of International Cooperation and Development}

www.richtmann.org/journal

Vol 3, No 2, November 2020

one, is made out of purple, white, and grey marble, with a combined façade which includes various ornamentals, as noticeable on the door and window toppings, which are typical to the Roman style. The central entrance is characterized by large columns which are supported by sculpted lions. A painting of Christ encircled by two angels is depicted on the arched ceiling above, whereas below it portrayed are the 12 zodiac signs. The western entrance has a relief which tells the story of Christ's baptism, and it also has an inscription from the architect written in Cyrillic. A number of other sculpted lions dominate the columns on the windows situated on the central apse, and similar zoomorphic and anthropomorphic depictions are repeated throughout the church's decoration (Laurent Mitchell, 2010).

It is interesting to note that other Orthodox monasteries do not have similar ornamental depictions, and it is particularly unusual to find sculpted lions, or other zoomorphic motifs, which are more typical for the Roman-Gothic style as seen in Italy and elsewhere in Europe, but also in the Adriatic coast. The fact that in its appearance this church differs greatly with other Orthodox churches, and that it shares many similarities with Catholic Churches, diminishes the attempts of Serbian scholars to categorize this church as an Orthodox monastery. Furthermore, some Serbian scholars willingly choose to ignore the appearance of the title friar, moreover completely neglecting the fact that the friar was an Albanian architect, by attempting to depict him as Vito Kotorian.

According to Qukiq, the church in Deçan was built by Stefan Uros the Third (Deçanski) and his son, Dusan. The church was built in the period stemming from 1327 until 1335, in accordance to the project created by Friar Vita from Kotor. A ctetorial inscription in Serbian dated between the years 1334-1335 mentions the protomagister Vita (Vitus) of Kotor serving as the lead constructor for eight years, and the presence of the title 'frad' (friar) and 'young brother' shows that he belonged to a Latin monastic order, and that he was a member of the Franciscan 'third order'. Aside from Friar Vita, the mason Gjorgje and his brothers Dobrosllavin and Nikolla also participated in constructing the church, whose origin was from Raska (Qukiq, 1973).

In general, the fact that the church was a masterpiece of Friar Vita Kuçi is often ignored, and the building is attributed to Stefan Uros III Deçanski and his son Dusan, who only financed the project, thus putting the focus on the Raska school of architecture, and never genuinely analyzing the outer façade.

The influence of Dalmatian-Albanian architecture came from Split, Raguza, Kotor, Tivari, Shkodra etc. The church in the monastery of Deçan preserves these elements pertaining to the Albanian-Dalmatian style. On the architecture of the southern entrance one can also find an inscription engraved by the Albanian architect, friar Vita Kuçi-Cuci. According to historical sources from the notarial office of Kotor, the Franciscan father, Vita Kuçi, was a rector and a prior of the church of Saint Mary in Kotor, a duty which in that part of the Adriatic was usually entrusted to Albanian monks. There are also other historical recordings that support the fact that father Vita together with 18 sculptors, built the Church 


\section{Journal of International Cooperation and Development}

www.richtmann.org/journal

Vol 3, No 2, November 2020

in the Monastery of Deçan (Drançolli, 2000). Some Serbian authors, such as Vlada Petkovic and Gjurgje Boskovic, are among the rare ones who confirm that the building was a project of the Catholic Albanian clergyman from Kotor, father Vito Kuçi, who oversaw the construction according to his project (Vlada Petkovic, Gjurgje Boskovic, 1941).

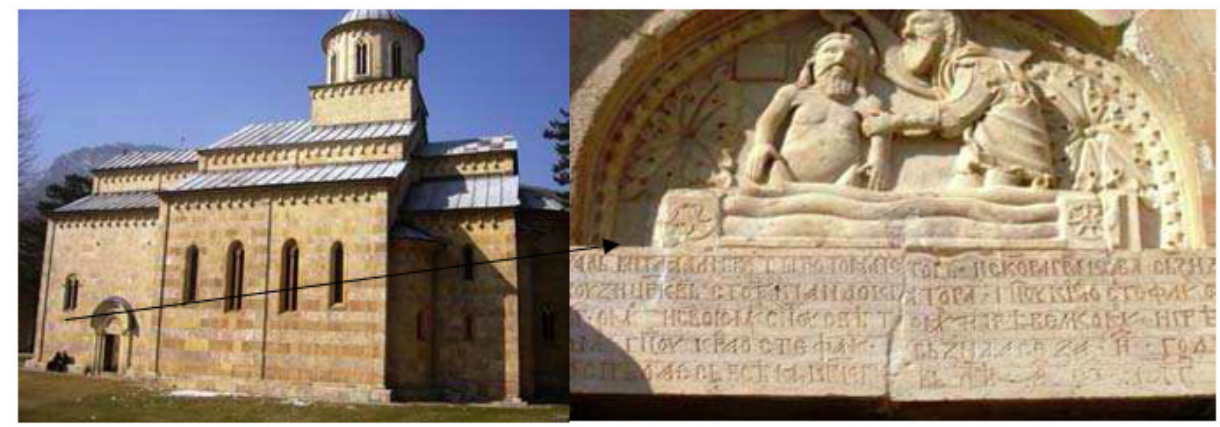

Fig: 1. The Catholicon, southern portal in the Monastery of Deçanit; 2 . The ctetorial inscription that mentions friar Vita

That the Serbs did not have such a tradition in construction is also confirmed by the Serbian author Pero Slijepcevic, as cited: 'These churches were not made by the Serbian rulers, whose name they bear, because at the time the 'Serbs' had no tradition of their own in building construction nor fresco painting. The Nemanyids have also (financed) to build churches outside the Serbian borders in order to promote their dynasty... Such monasteries have been financed in Jerusalem, Istanbul, in Greece and elsewhere' (Pero, 1934). Before we move on to discuss the outer façade, which speaks clearly of the church's cultural background, there is another element which favors the argument that the monastery was built by the Franciscans, specifically an Albanian monk who was a master mason and an architect, considering that Kotor had a great influence on a large part of the Serbian territory.

In the past, the territory of the Kotor diocese has changed repeatedly. By the 13th and 14th century, the borders of the diocese of Kotor had expanded all the way to the Danube. At the time, under the jurisdiction of the bishopric of Kotor were Prizren, Janjeva, Novobërda, Novi Pazar, Brskovo, Bllacë, Brvenik, Pllana, Mačva, Trepça, Targovishte and Belgrade. Furthermore, by the 16th century the Bishop from Kotor, Tripo Bisanti (15131540) was signed as a bishop of the entire Serbia, 'Totius Serbiae'. Certainly, this was related to the Catholics in Serbia (Ilija, 2009).

We can conclude from this that the bishopric of Kotor - the Franciscans, was expanded towards the most remote towns in Kosova, let alone the region of Deçan or Peja, which are in close proximity to Montenegro, divided only by a mountain, which is closer than any other town in Kosova. The bishopric of Kotor was directly related to the 


\section{Journal of International Cooperation and Development}

www.richtmann.org/journal

Vol 3, No 2, November 2020

region also through the monks that hailed from these areas. From this, we can conclude that it is not by accident that the unique architecture of the monastery of Deçan, which is more similar to monasteries of Italy, highly likely exists because the monastery was a Catholic Church which was later captured by the Orthodox Serbs, and appropriated as their own. Because of this, the Serbs continue to insist that the church is their own, a claim which has little to no scientific merit.

If we are to consider the fact that after the Slavs settled in the Balkans, they left no cultural traces of being an agrarian society, and there is little evidence to support the fact that they have had anything other than a limited collective political life, ultimately having left no history as M. Le Baron d'Avril says (M. Le Baron d'Avril, 1896). Consequently, we cannot in all sincerity speak of any architectonic tradition pertaining to the Serbs, nor can we make a claim that there is a specific architectonic Serbian style even today. If we add to this the fact that the Serbs were Christianized by the Albanians, who were already at the time an agrarian and civilized society, it is logical to assume that the Serbs imitated the Albanian culture and civilization. The first official baptism of the Slavs occurred in 86466 when the Bulgarian king Boris ruled, as confirmed by his seals and an inscription found in the vicinity of the city of Ballsh, in Albania (Бакалов, 1907). After the Bulgarians converted, the Serbs accepted Christianity during the reign of Knez Mutimir in 891, (Radmila, 2007). however, we cannot speak of a mass conversion, considering that they accepted Christianity in a gradual manner. The earliest document of baptism that confirms the conversion of South Slavs, from the Byzantine perspective, pertains to the mid-10th century and was written by the Byzantine emperor Constantine Porphyrogenitus - De administrad imperio (Gy. Moravcsik, 1967). In the chapters 29, 30, 31 and 32, the author pays attention to the question of Serbian baptism (B. Ferjančić, 1959). This confirms that the Slavs had not been Christianized in a singular phase.

A similar perspective that depicts the baptism of South Slavs can be found in another act produced in court - Vita Basilii (after June of 950), highly likely written by Constantine Porphyrogenitus himself (Bury J. B. 1906). However, the version given by Vita Basilii is somewhat different, seeing that it claimed that the majority of these Slavs, not only shook the Byzantine reign, but they also abandoned the holy baptism in the process (Theophanus Continuatus, 1838). So, the first Christian churches of this ethnic group are Catholic, and the Orthodox ones appear only in late 11th century after the schismatic division. If we follow this trajectory, it is easily noticeable that the Serbs have appropriated the Catholic Churches in a strategic manner, considering that the Serbs had neither the tradition nor any Christian familiarity.

That Serbs have had no tradition in construction is also confirmed by Hoddinot. Most artists, who considered themselves master masons, during medieval times, were not from the monastery ranks. The engravers who worked with wood, in fact, came from one pastoral tribe, namely from Mijaka, who came from Galiçnik in the vicinity of Dibra, bordering with the current Albanian border. 


\section{Journal of International Cooperation and Development}

www.richtmann.org/journal

Vol 3, No 2, November 2020

We do not know with certainty if this tribe was responsible for the survival of the first examples of the early Macedonian style, which can be found today in Ohrid, Slepçe, the Patriarchate in Peja and Deçan (R. F. Hoddinott). but what we know for sure is that they worked on the most exquisite creations of the first half of the 19th century, which can be seen today in the monastery of Saint Jovan Bigorski and Lesnovski and in various churches in Skopje, Prishtinë, Prilep, Manastir, Štip, Kruševo, and in other places. The characteristics of these creations which were repeated in all the works pertaining to this style of the Mijaku craftsman, have a free hand shape and display naturalistic elements, with a sufficient vitality and originality, free of oriental elements and repetitive monotony.

The buildings financed by the Nemanyids belonged to the western style. According to the scholar Kondakov, the white marble church of Studenica is a western church of the Longobard Dalmatian style. The church of the monastery of Moraça (1252) has a Roman portal with primitive sculptures above an ornamental topping. Ziça and the church of Queen Helena, the widow of king Uros I, in Gradac of Rashka, are both Byzantine style buildings, combined with Romanic and Gothic displayed on the windows and doors. We cannot agree with Jireçek's conclusion in regards to the transformation of the interior of the church, especially regarding the icons and frescos, because in most Orthodox churches there are several layers of painting, meaning that the interior of the church was transformed depending on who was the ruler. This has oftentimes been done in order to remove traces, because many Catholic churches were transformed into Orthodox ones. We can trace a similar occurrence with the case of the monastery of Deçan, which is a grand construction in its own, composed of several layers of stones and colored marble; with the presence of anthropomorphic and zoomorphic sculptures depicting a church more akin to the western style (Jireček, 2010).

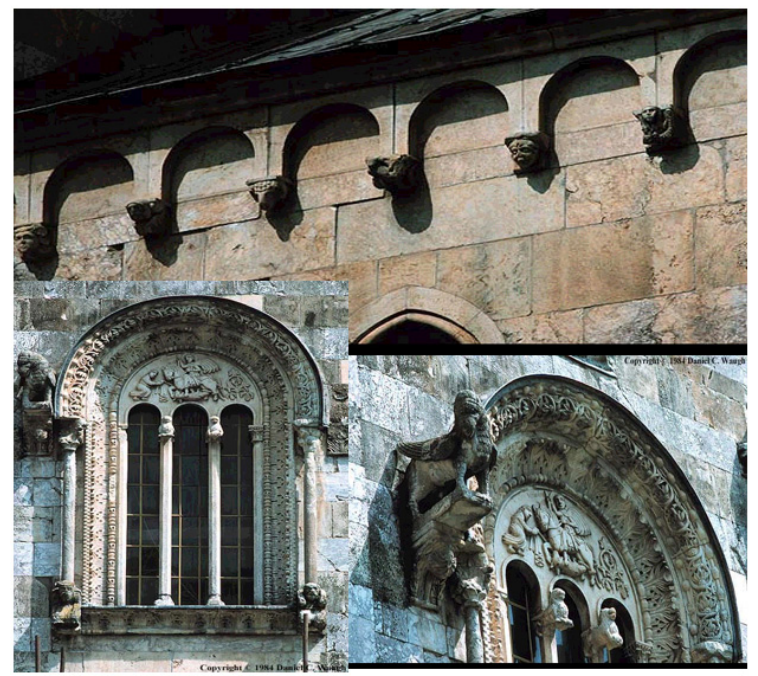

Fig: Typical examples of Roman-Gothic architecture, zoomorphic motifs. 


\section{Journal of International Cooperation and Development}

www.richtmann.org/journal

Vol 3, No 2, November 2020

In regards to the monastery of Deçan, Jireçek is quite right in assessing that the accompanying architecture of the monastery contains local elements more than Slavic and Byzantine ones, add this to the fact that Vita Kuçi had worked with 18 other local stone masons.

Another element which is in favor of the argument we present here, is the demography of the region, where the majority of the population was Albanian, regardless whether they are Catholic, Orthodox or Muslim. In this regard, it is important to mention a document from the year 1335 which speaks of the ethnic structure of the local population.

The document was retrieved from Acta et diplomata res Albaniae mediae aetatis illustrantia. Vol. I, Annos 344-1343, tabulamque geographicam continens collegerunt et digesserunt Dr. Ludovicus de Thalloczy, Dr. Constantinus Jireek et Dr. Emilianus de Sufflay. 1913-1918. Vindobonae page 237.

\section{Doc. 798 , year 1335}

Stephanus Dusan, Serbia rex, monasterio Deçani (inter alia) vicum in Zeta Krusevo nominatum cum viculis et confinibus currentibus a terminis (pagi) Kupelnik) per viam vici, prope terminus (pagi) Kamenica in lacum, inde proper terminus s.Stephani versus Kamenicam, per rivum Nereda in viam vici donat, in quo vico: Paulus et Bushat cum liberis, Georgius Daiç, Gin Cerasovic, Gon Michil, Dminko Barda, Nicolaus Kaltanic, Paulus Busadosa, Lazor, Dminko Daic, Nicolaus Der, Lazor Let et Gerkinja cum liberis, Nicolaus Let, Paulus Nerac, Andreas Nerac, Dminko, Progon; donat porro,, vicum pastoralem Albanensium: Les, Tuz) et cum liberis", Branislav Qurko cum liberis et fratribus, Svinoglav, Gon Busat et Gon et Petrus et Gin, Grataj Georgic et Budan, Petrus Suma) Mataguz cum fratribus, Lazor et Prijezda, Kreq cum liberis, Gonoma, Dminko et Lesh, Dimitrius cum fratribus, Andriqko cum fratribus, Petrus cum fratribus, Req cum liberis, Lesh et Lazor, Progon Mira) Petrus Kuq cum fratribus, Paulus cum liberis, Dminko cum liberis, Nicolaus cum liberis, Nicolaus, Paulus cum fratribus, Michael et Dimitrius, Golub et Gon cum fratribus, Georgius et Shok et Teshemir, Marcus Suma et Mizko et Pelegrin... Dajak cum liberis, Bogoslav (Sufflay, 1913).

The names of Albanian villagers are mentioned in the year 1335 in the act of gift giving of Stefan Dushan for the Monastery of Deçan. Although the names have been modified, it is clear that they represent pure Albanian names. However, from that time onwards, the Albanian names have been changed and altered in order to adapt to the Slavic form, thus continually manipulating the historical tradition. From here we can deduce another conclusion on the structure of the majority of the population, which were the Albanians, and also deduce that the Monastery of Deçan cannot be appropriated because not only were the Albanians the majority, but they also helped and contributed in various ways in maintaining the monastery. This is additional evidence that the 


\section{Journal of International Cooperation and Development}

www.richtmann.org/journal

Vol 3, No 2, November 2020

monastery as such, cannot be called in any way a Serbian monastery, considering that it also represented a sacred temple for Albanians as well, regardless whether they were Catholic who conducted regular pilgrimages there, or those who were Orthodox and attended the mass at the monastery.

In the document 746 of the year 1330, July 18th, in relation to a gift giving act by Stefan Urosh III, Serbian King, it is stated that he gives to the Monastery of Deçan many 'villages and Vlach and Albanian pastoral fields... (Sufflay, 1913). thus, not mentioning any Serbian villages, but rather confirming that the local population was in majority Albanian.

Such attempts to culturally assimilate the Albanians have not ceased even today. The most typical case for an analogy with our contemporary times is the large number of political Orthodox churches built in various cities throughout Kosova, culminating with the political church built at the center of the University campus in Prishtina during Milosevic's regime. Despite these culturally aggressive acts, the Serbs continue to play the victim's role. We have to recall that during medieval times, continuing well into the Ottoman period, the Serbs had accepted fealty and profited enormously economically, in which case their Orthodox churches remained intact, a privilege that the Albanians did not enjoy. On the other hand, we do not have any cases where an Orthodox church was transformed into a mosque during the Ottoman era, spare the Church of St. Premte (Xhuma Xhamia) in Prizren, and that only for a brief time. Catholic churches were far less spared. This may lead us to the conclusion that this has been done in a synchronized manner between the Serbs, the Orthodox Church and the Ottomans. To the Ottomans, the Albanians represented a group that was not subjugated, regardless whether they had already converted to Islam or not. It is because of this that the Serbs had received a free pass to act towards the Albanians as they wish, going unpunished by the Ottomans.

If we are allowed to draw a parallel, we would do so by recalling the gentleman's agreement between the Yugoslavs and the Turks on April 11th of 1938, where the Serbs were not forced to move to Turkey, but only the Albanians and the Bosnians were forced to do so. This behavior can be traced all the way back to medieval times, from the times of the Nemanyids, where we cannot exclude the process of appropriating the Albanian Catholic churches and claiming them as their own.

However, let us return once again to the charter of Deçan, published in the year 1330 from Stefan Deçanski, where we can see that this region represented a heavily populated area. If we refer to the documents, we can see that the majority of the population of these areas had already been Islamized, whereas the number of Orthodox Albanians who had preserved their faith had been assimilated in time, but they preserved their Albanian traditions (Rizaj, 1971).

Ever since the Great Schism of 1054, the Albanian lands were divided between the influences they received from their Greek and Slavic neighbors, and the influences from Rome and Venice. In the 13th century, the Serbian Orthodox Church declared itself independent from the Byzantine church, and ever since then it has cooperated greatly 


\section{Journal of International Cooperation and Development}

www.richtmann.org/journal

Vol 3, No 2, November 2020

with central state politics. The Autocephalous Orthodox Serbian Church was established by Sava Nemanyic, whom the Church proclaimed a saint. Ever since its beginnings, the Serbian Church displayed its aggressive politics towards the Orthodox clergy that was not Serbian. A concrete example of this is when Sava expelled the bishop of Prizren who was of Greek origin, and in his place a Serbian bishop was appointed. The Serbian Orthodox Church had exceeded its religious competences and transformed into a nationalist church, whereas the Catholic Church maintained its universal principles by recognizing the Pope of Rome. The Serbian Orthodox Church coordinated propaganda with the central state powers, which greatly influenced their national cohesion. The Church became a strong element in the attempts of the state to unify all Serbs, including those who lived outside the Serbian borders, with the Serbian empire of Tsar Dusan in the 14th century (Krasniqi, 1994).

The policies of the Serbian reign, with the blessings of the Church, followed a path of violence and terror. In the code (kanun) of Tsar Dusan, one can find there very strict punitive measures towards those who converted to Catholicism. The Catholic clergy were persecuted, and the Catholic churches were captured and transformed into Orthodox churches. The Serbian Church and state undertook severe and inhumane measures to assimilate the Albanians. The newborn babies were given Slavic names, and similar acts were done with sacraments, in which cases marriages were carried out in the Serbian language. As a result of these pressures, many Albanian families in Kosova, Macedonia and Montenegro have been assimilated. In Montenegro, Albanian tribes such as Kuçi, Bjellopavliq (Palabardhët), Piprraj, Vasoviq, and others were among the assimilated ones (Krasniqi, 1994). This proves that the Serbs had initiated a complete assimilation campaign of the non-Slavic population, and that this campaign has been ongoing ever since then. We see reflections of similar policies portrayed in the political platform of Načertanije in 1844 , where the Church is placed at the center of this ideology, which continues to be executed to this day without being able to free itself from its hegemonic views.

All the monasteries in Kosova are considered by the Serbs as monuments of culture from the medieval period of Nemanyids, appropriating in this manner all the cultural monuments that were not initially theirs. One Serbian scholar, Pero Slijepeviqi, expresses himself in the most decisive way: 'It was been proven that from the large number of old Serbian monasteries, only a small number of them were established by Serbs, in accordance to the inscription they left on the buildings... The Serbs had no tradition of construction of their own, nor in painting' (Krasniqi, 1994).

Aside from the visible Byzantine architectonic elements present in the Monastery of Deçan, one can also observe important architectonic elements pertaining to the Roman Italian style (Elsie, 2011). It appears that Elsie was not quite familiar with architecture, because contrary to his claim, the Roman-Gothic elements are ever present and combined with the Byzantine elements, and not Slavic ones. This occurs because the Slavic style is not developed until the Ottoman era, which is also quite different to the style in which 


\section{Journal of International Cooperation and Development}

www.richtmann.org/journal

Vol 3, No 2, November 2020

the Monastery of Deçan is built, as can be easily confirmed when observing other Slavic monasteries which look different, wherein the Byzantine style is dominant.

In regards to the Monastery's similarity to those in Italy, we have a very interesting information which comes from a relation of the sub-prefect of a religious mission in Albania, friar Kurbin. During his visit in Gjakova and its vicinity in 1638, among other things, he describes the Monastery of Deçan as a beautifully built monastery and compares it to the churches in Italy, and that among the six monks he had met at the church, he had also met one who spoke Albanian (J. Radonic, 1950).

The renowned scholar Zamputi, adds that aside the fact that the Monastery of Deçan looks similar to the monasteries in Italy, built beautifully with varying stones and a cupola, with marbles filled with beautiful paintings depicting the life of Jesus Christ, Saint Mary, of the apostles, the patriarchs, the prophets, the saints and other..., the Monastery of Deçan is inhabited by 30 schismatic monks (Zamputi, 1965). If we observe the interior of the church, for example the icons and frescos, we notice that there are several layers of iconographic depictions stratified throughout history, some of which are similar to the Italian style.

The acts of the church frescoes in the 14th century are worthy of more intensive research in order to shed light on the topic. Although they were created at a later date, they certainly offer information regarding an earlier period of the church, and for this reason they are valuable in researching the Byzantine iconography of the church. From all Eastern examples, Deçan is the closest to the iconography of Vercelli-Verona, creating thus a connection between the Italian representation and the early Byzantine of similar subjects (Luba Eleen, 1977). Other main elements that speak for the style and the cultural background of the church, are to be found in the outer decorative plastic.

The attempts to appropriate were increased when the Serbs realized that they could gain a favorable position with Byzantine and the Papacy in relation to the threat posed by the Ottomans.

The Serbs took advantage of the situation created in the 14th century, especially with the weakening of Byzantine, as well as taking advantage of the emergence of the Ottoman threat. They agreed to become vassals to the Ottomans, and managed to preserve their religious and cultural autonomy. These attacks paved the way for the ecumenical proximity between the Catholic Church and the Orthodox one, in order to form a joint front against the impeding Ottoman threat. Because of this, the Serbs had a favorable position, despite the fact that they had established principalities and kingdoms that rebelled against the Byzantines; they were still endorsed by the western church, in the name of Christian unison.

Although the death of the Serbian king, Stefan Dushan (1355), led to the decrease of the military threat that the Serbs could pose, their behavior of systematic looting and capturing the Turkish settlements in the former Byzantine territories of Minor Asia and Europe would not cease to occur. The situation in which Byzantine was greatly weakened 


\section{Journal of International Cooperation and Development}

www.richtmann.org/journal

Vol 3, No 2, November 2020

from the inside, and the impeding Ottoman threat, was a strong incentive for the actions that Gjon V took, as a lone emperor of the empire: In 1355, he proposed to the Pope Innocent $\mathrm{VI}$ to rejoin the Byzantine and Roman Church in order to form a military alliance against the Ottomans (A. Theiner, 1872). Even during the year of civil strife, the emperor Gjon Kantacuzeni had established his relations with the Papacy, by expressing a serious interest in unifying the Churches. Although the influence of Kantacuzen in the religious life was noticeable, as scholars have noted (See J. Meyendorff, 1960). it appears that there were little chances that the young emperor Gjon $\mathrm{V}$ had made this detailed and unusual proposition with the advice of his father-in-law.

If we view these developments, it is understandable that the Serbs were interested to maintain good relations with both Rome and Constantinople, and the construction of the Monastery of Deçan in itself speaks of this diplomacy to appeal to both Churches, and gain great favor if the Churches were to unite again. The presence of the Roman-Gothic elements, as well as the high number of the Catholic population who lived in these areas, speak of the fact that the monastery as such was not considered a Serbian one. The attempts to appropriate it are numerous and often futile to the local population, for reasons mentioned above. As such, it is factual to state that the Roman-Gothic style, which is characterized with anthropomorphic, zoomorphic and floral elements, is hardly characteristic of the Orthodox Serbian monasteries. If we add to this the fact that the Albanian population who were initially either Catholic and Orthodox were forcefully converted to Islam, as well as the relations with Rome, and the emergence of the Ottoman threat, all speak in favor of the theory that the Monastery of Deçan was not, and could not have been Serbian, especially if we take into account that churches and faith in itself cannot be appropriated

To paint a better picture the manner in which the Serbs had appropriated churches, not only in Kosova, but elsewhere too, we can recall the case of the Assemly of the Trinity Chapel, later on known as the Serbian Orthodox Cathedral of Saint Sava, a historical church situated on the Western side, block 15, no. 25, between Broadway and 6th Avenue in the neighborhood NoMad of Manhattan, New York City. The building of the church was constructed between the years 1850-55 and was designed by the architect Richard Upjohn in the style of revived English Gothic ((Dolkart, Andrew S. Postal, Matthew A. 2009). It was initially constructed as one of the main churches of parish of the Church of Trinity, but it was sold to the Eastern Orthodox Serbian parish in 1942, and it was later reopened as the Cathedral of Saint Sava in 1944. A Serbian Orthodox congregation, established in 1930, bought the building of the Trinity church in 1942, helped greatly by various Serbian churches, and the building was reopened in 1944 as a Serbian Orthodox Cathedral dedicated to Saint Sava, protector saint of the Serbs. The first minister of the church was Dushan Shoulkletovich. Peter II, the last king of Yugoslavia, took part in the sacraments performed in this church (Dunlap, David W. 2004).

If we are to consider this fact, then it is quite obvious that we cannot claim that the 


\section{Journal of International Cooperation and Development}

www.richtmann.org/journal

Vol 3, No 2, November 2020

Orthodox Church, Trinity Chapel, in New York can be categorized as a Serbian Orthodox Church and a monument of their cultural heritage, because it is part of the American cultural heritage, situated in American soil.

We have a higher level of appropriation and assimilation of traditional Albanian culture in Kosova (Zeiller. J. 1918). The Albanians, respectively the Kosovar Albanians, are an autochthonous population and one of the earliest who have accepted Christianity, to which the existence of the early Christian martyrs, St. Flori and St. Lauri, can testify (Acta Sanctorum, 1737). There are also early Albanian Christian centers such as Ulpiana, numerous castles and fortifications dating from antiquity, and medieval cities such as Novobërda. There re numerous Catholic churches built in each one of these, which the Serbian historiography has continuously attempted to appropriate. Furthermore, the Serbian Orthodox Church in coordination with the Serbian regime has forced the Catholic Albanians to change their names, and they have also changed the Albanian toponomy, mostly because they were territories in which they had properties. Everything that belonged to the Orthodox faith was considered Serbian, including the names of the villages.

On the other hand, there is evidence to support the argument that this monastery was considered a place of worship by Albanians. For centuries on, the Albanians in Kosova have preserved, protected and maintained the medieval Orthodox churches and monasteries, which stand to this day unharmed. The Orthodox churches were considered by Albanians as churches of their ancestors, and they were therefore sacred to them. That these places of worship were used by their predecessors can be confirmed through historical photographs.

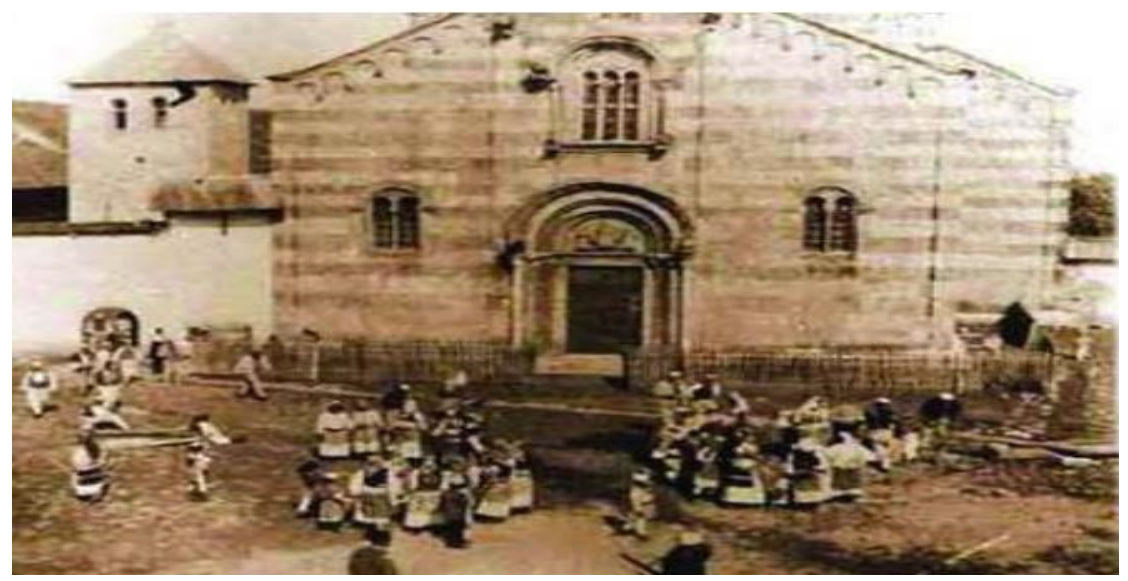

Fig: Dressed in typical Albanian clothes, one can see Albanian followers in the frontyard of the church. 


\section{Journal of International Cooperation and Development}

www.richtmann.org/journal

Vol 3, No 2, November 2020

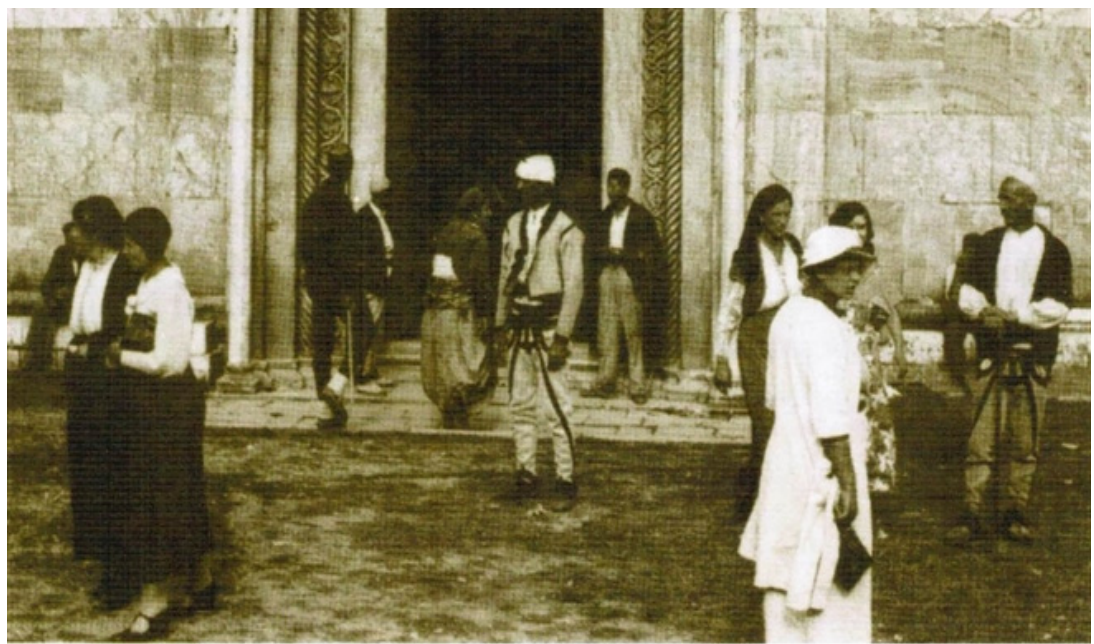

Manastiri i Decanit. Fotografi anonim / 1915-1918

Fig: The Monastery of Deçan

The Monastery of Deçan attracts many tourists and pilgrims from all over the world, and it represents an important sacred place, historical monument, and a medieval building representing medieval art, to be shared and acknowledged by all.

\section{Conclusion}

The logic of appropriation and alienation of heritage must remain distant because the civilized world does not accept it. If the various peoples had acted to divert from the hereditary past, it would have caused unrest, chaos and even wars. Of all that has been seen and treated about this monastery which, even if it was Serb, would not have had the right to qualify it as Serbian property because it was built by an Albanian Franciscan Vita Kuqi from the basis of the name, with an architecture and a style that have nothing to do with the Serbs, with the gifts of a Serbian prince, a monastery that served everyone. Thus, the case of the Deçani monastery with its Romanesque and Gothic architecture and its past enriches the cultural mosaic of Kosovar cultural heritage with at least something to do with the Serbs. Therefore, everything in the territory of the Republic of Kosova is part of the Kosovar cultural heritage and, as such, should not be classified as a Serbian heritage since this monastery was preserved by the Albanians themselves because the locals considered it their own. The images seen of the Albanians visiting the monastery make us understand that generations have made pilgrimages there and as such it is also a sacred place for the Albanians, therefore historical law does not belong to anyone. After all, the very fact that it is the house of the gods where people pray regardless of race or colored nation which is the mission of any monotheistic religion refutes the logic of excluding an 


\section{Journal of International Cooperation and Development}

www.richtmann.org/journal

Vol 3, No 2, November 2020

ethnic group from attributing the right to another. So, over the centuries, the Albanians have also been Orthodox, regardless of strength or otherwise, and that the monastery was a place of prayer for the ancestors of the inhabitants of this region and beyond, and as such, it is everyone's house, it belongs to everyone. Everyone is equal in God's eyes and I would have called on the religious leaders to spread messages of peace of understanding and not to widen the gap of hatred and once and for all the church should not be involved in politics.

\section{References}

A. Theiner. P. Miklosich. (1872). Chrysobull published in Monumenta Spectantia ad Unionem Acta Sanctorum XXXV die 18 augusti III. (1737). Antverpiae, 520, 522.

B. Ferjančić. (1959). DAl. 29.58-76. See also commentary of: BИИНJ. 1959. Т. II. С. 14-16, 22, 26. Bury J. B. (1906). DAI. For the date of the compilation (c. 950) of the Vita Basilii, The Treatise De administrando imperio BZ. 1906. Bd. 15. S. 551, 573.

Dragan Qukiq. (1971). Kosova monumentet dhe bukuritë, Lidhja turistike e Kosovës, Prishtinë, 132. Drançolli, Jahja. (2000). Monumentet e kultit katolik gjatë mesjetës në Kosovë, Konferenca Ipeshkvnore e Shqipërisë, Krishterimi ndër shqiptaret, simpozium ndërkombëtar Tiranë, 1619 nëntor 1999, Shkodër, 147.

Dunlap, David W. (2004). From Abyssinian to Zion: A Guide to Manhattan's Houses of Worship. New York: Columbia University Press, 244.

Elsie, Robert. (2011). Fjalori historik i Kosovës, Tiranë, 108.

O. Halecki. (1930). Un empereur de Byzance a Rome. Vingt ans de travail pour Vunion des eglises et pour la defense de Vempire d'Orient, 1355-1375, Travaux Historiques de la Societe des Sciences et des Lettres de Varsovie Warsaw, 31-59.

Gy. Moravcsik. (1967). Constantine Porphyrogenitus. De administrando imperio, Greek text ed. by; Engl. transl. by R. J. H. Jenkins. Washington, 1967 (DAI). The commentary on the DAI was published separately: Constantine Porphyrogenitus. De administrando imperio. Volume II: Dvornik F., Jenkins R. J. H., Lewis B., Moravcsik Gy., Obolensky D. Runciman S. Commentary Ed. by R. J. H. Jenkins. London, 1962.

J. Gill. (1979). Byzantium and the Papacy, 1198- 1400, New Brunswick, N.J., 208.

J. Radonic. (1950). Rimska Kurija u Jugoslovenske zemlje, od XVI do XIX veka, Beograd, 104. Jastrebov. (1904). De situ cf, Jastrebov, Stara Srbija i Albanija Spomenik. 41 (1904), 58.

Jireček, Konstandin. (2010). Historia e Serbëve, Pjesa e dytë, Tiranë, 98.

Kosova dikur e sot. (1973). Beograd, 422.

Krasniqi, Mark. (1994). Roli i Kishës ortodokse serbe e greke në politikën antishqiptare, Gjurmime albanologjike, Folklor dhe etnologji, 23 -1993, Prishtine, 82.

L. Maksimovic. (1966). Politicka uloga Jovana Kantakuzina posle abdikacije (1354-1383)', ZR, ix, 119-88 (English summary, 189, 93.

Laurent Mitchell. (2010). Serbia Guide, Connecticut, 313.

Ilija, Janjic. (2009), Liturgijski Vodic Sredisnje Liturgijsko Slavlje, biskup Kotorski, Kotor, 78.

Luba Eleen. (1977). Acts Illustration in Italy and Byzantium: ne Dumbarton Oaks Papers, Vol. 31, 253, 255, 278. 


\section{Journal of International Cooperation and Development}

www.richtmann.org/journal

Vol 3, No 2, November 2020

M. Le Baron d`Avril. (1896). La Serbie Chretienne ne Revue de L’Orient Chretienne vol 1 Paris,9. Mijovic. P. (1962). Flor I Lavr-neimari I kamenoresci iz Ulpijaneu GMKM VII-VIII. 339, 353.

New York City Landmarks Preservation Commission. (2009). Dolkart, Andrew S.; Postal, Matthew A. Postal, Matthew A. (ed.). Guide to New York City Landmarks (4th ed.). New York John Wiley \& Sons, 80.

Nickles H. G. (1937). The Continuatio Theophanis Transactions and Proceedings of the American Philological Association.. Vol. 68, 222, 224.

Pero Slijepcevic. (1934). Stare Srpske Zaduzbine, Beograd, 92, 122.

R. F. Hoddinott. (1954). The Tradition of Wood Carving in Macedonia, The Burlington Magazine, Vol. 96, No. 618, 278, 283.

Radmila Radic. (2007). Serbian Christianity in "The Blackwell Companion to Eastern Christianity, Blackwell, 232.

Rizaj, Skënder. (1971). Një dokument i fillimit të shekullit XVIII mbi kufizimin e bjeshkës së Deçanit dhe mbi popullsinë e Deçanit, Lloqanit dhe Carrabregut, Vjetari i Arkivit të Kosovës, Nr. IV-V, Prishtinë, 238.

Rogosic, R. (1962). Veliki Ilirik (284-395) Zagreb, 307.

J. Meyendorff. (1960). Projets de concile oecumenique en 1367s, DOP, xiv, 149, 52.

Ševčenko I. (1978). Storia letteraria La civiltà bizantina dal IX all' XI secolo. Bari, 99, 101.

Kazhdan A. (2006). A History of Byzantine Literature (850-1000) Ed. by C. Angelidi. Athens, 137, $144,29,68,84,30,87$.

Sufflay, Milan, (1913). Emilianus. 1913, Acta et diplomata res Albaniae mediae aetatis illustrantia. Vol. I, Annos 344-1343, tabulamque geographicam continens collegerunt et digesserunt Dr. Ludovicus de Thalloczy, Dr. Constantinus Jireek et Dr. Emilianus de Sufflay, 1913-1918. Vindobonae, 222.

Theophanus Continuatus. (1838). Ioannes Cameniata. Symeon magister. Georgius monachus Ed. I. Bekkerus. Bonnae, Theoph. Cont, 288, 12, 289. 2.

Vlada Petkovic, Gjurgje Boskovic. (1941). Manastir Decani, Knj. I, Beograd SANU, 1, 18.

Zamputi, Injac. (1965). Relacione mbi gjendjen e Shqipërisë veriore e të mesme në shekullin XVII, Vëllimi II (1634-1650), Universiteti Shtetëror i Tiranës, Instituti i Historisë dhe i Gjuhësisë, Tiranë, 107.

Zeiller J. (1918). Les origins chrétiennes dans les provinces danubiennes de l'empire romain, (Biblioth. des Écoles françaises d'Athènes... Paris, E. de Boccard, 103, 104, 107,

Бакалов, Георги. (1907). Средновековният български владетел. (Титулатура и инсигнии), София (1995). Бобчев, С. С. Княз или цар Борис? (към историята на старобългарското право). Титлите на българските владетели, Българска сбирка, XIV, 5. 311. 